\title{
Norske redaktører som eksportvare
}

\author{
Hvorfor er så få norske leger representert i internasjonale tidsskrifter? Redaksjonelt \\ arbeid skjerper den analytiske evnen, styrker evnen til å tolke forskningsresultater \\ og gir innsikt i faglige prosesser og endringer.
}

Norske leger er svakt representert i redaksjonene i de høyest rangerte fagtidsskriftene. Det er et problem - både fordi vi i lille Norge har et uttalt og allment anerkjent behov for internasjonalisering og fordi norske leger dermed går glipp av en unik erfaring som ikke bare gir dem viktig faglig input, men også kan ha betydning for deres kliniske virke. Hvorfor er det slik? Befolkningsstørrelsen alene kan ikke forklare hvorfor det sitter flere svensker, finner og dansker enn nordmenn i internasjonale fagmedisinske redaksjoner. Min udokumenterte påstand er at selv Island (med et befolkningsgrunnlag på linje med Rogaland fylke) har flere fagredaktører og redaksjonsmedarbeidere i ulike medisinske tidsskrifter enn oss. Hvordan kan vi endre dette? Muligheten for å delta uforpliktende som en «lærling» i redaksjonsarbeid er allerede til stede på flere medisinske fagområder (1), men benyttes i liten grad av norske leger.

Tidsskrift for Den norske legeforening har helt siden 1881 hatt en sterk posisjon i norsk medisinsk publisering. Mange norske klinikere og forskere har via Tidsskriftet fått sin første erfaring med manusinnlevering, fagfellevurdering, manusrevisjon og vitenskapelig publisering. Tidsskriftet fyller ikke bare en oppdragerrolle for norske leger som forfattere og lesere, men er også viktig for skolering i redaksjonelt arbeid. Kanskje det ligger et uforløst potensial i eksport av norske redaktøremner til internasjonale tidsskrifter?

\section{Egen erfaring}

Jeg har selv vært medisinsk redaktør i Tidsskriftet, er redaktør i Scandinavian Journal of Trauma, Resuscitation and Emergency Medicine og har nylig vært ett år i et ledende kirurgisk tidsskrift. De siste årene har British Journal of Surgery utlyst to stillinger som «editorial assistant», og undertegnede fikk denne muligheten i 2008/2009. Dette er en ulønnet «lærlingstilling» hvor man får være med på de redaksjonelle prosessene, behandle manus, diskutere innhold og saker, og følge et helt «redaksjonsår». I tillegg får man muligheten til å utføre et publiseringsrelatert prosjekt sammen med en mentor i redaksjonen $(2,3)$. Tidligere redaksjonserfaring er ikke noe krav. Undertegnedes erfaring som medisinsk redaktør i Tidsskriftet var nok en fordel, og noe som gjorde det lettere å få innpass i de redaksjonelle prosessene og bidra aktivt i diskusjonene. Året ga meg også mulighet til å skrive to lederartikler $(4,5)$. Stillingen som redaksjonsassistent er svært populær, og til årets stillinger var det nærmere 50 søkere fra hele Europa - men ingen fra Norge.

\section{Kirurgisk tidsskrift}

British Journal of Surgery er et ledende internasjonalt, generelt kirurgisk tidsskrift med en historie tilbake til 1913. Målt etter impaktfaktor er det det høyest rangerte kirurgiske tidsskriftet i Europa og det nest høyest rangerte på verdensbasis, kun passert av Annals of Surgery. Redaksjonen er satt sammen av kirurger fra hele Europa, med representanter fra ulike nasjonale eller fagspesifikke kirurgiske foreninger som er tilnyttet tidsskriftet. For noen år tilbake ble European Journal of Surgery og Swiss Surgery innlemmet i tidsskriftet. Medlemskap gir både innflytelse i styret og tidsskriftsabonnement for medlemmene i de kirurgiske foreningene. I motsetning til det som er tilfelle i Sverige, er verken Norsk kirurgisk forening eller noen av underforeningene assosiert medlem av BJS. Følgelig er det heller ikke nordmenn med i styret eller «editorial board».

BJSs internasjonale fokus vises også ved at hovedtyngden av de publiserte artiklene de siste tiårene er blitt levert fra land utenfor Storbritannia, særlig fra andre land i Europa $(6,7)$. Mer enn 1200 manuskripter sendes inn årlig, hvorav knapt $15 \%$ aksepteres for publisering etter en omfattende faglig og redaksjonell prosess. BJS er at av de tidsskriftene som mottar og vurderer flest randomiserte studier innen fagområdet kirurgi, og arbeider publisert her er ofte retningsgivende for endringer innen kirurgien. Redaktørene møtes månedlig i Royal College of Surgeons' lokaler i London i tillegg til faste møter i forbindelse med den årlige britiske kirurgikongressen og ved seminarer om tidsskriftrelaterte emner, som artikkelskriving og fagfellevurdering.

Michael Bretthauers og mitt arbeidsopphold i henholdsvis New England Journal of Medicine og British Journal of Surgery hadde sannsynligvis ikke vært mulig uten
Tidsskrift for Den norske legeforening som springbrett. Min erfaring er den samme som Bretthauers: Tidsskriftets redaksjonelle arbeid står seg godt i internasjonal målestokk (8).

Kanskje burde flere unge leger og forskere i Norge søke uforpliktende erfaringer som «redaktørlærling» i tidsskrift, enten her hjemme eller i større internasjonale tidsskrifter som BJS, Radiology og NEJM, for å få en redaksjonell førstehåndserfaring. Dette er uforpliktende for begge parter, men gir mulighet for å høste erfaring og se prosesser fra innsiden.

\section{Kliniker og redaktør}

Alle leger, enten de arbeider klinisk eller med forskning, vil ha nytte av redaksjonelt arbeid. Det skjerper den analytiske evnen og styrker evnen til å tolke forskningsresultater. Dessuten blir man bedre til å fremstille kompliserte saksforhold på en god og tilgjengelig måte. I tillegg gir altså også en slik erfaring en unik mulighet til å komme seg ut i den internasjonale tidsskriftsverdenen. Redaksjonelt arbeid består av evaluering, redigering og publisering av diagnostiske og terapeutiske funn og er noe som angår et stort antall pasienter. Godt klinisk legehåndverk kan helbrede, lindre og hjelpe enkeltpasienter. En redaktør kan gjennom publiseringsvirksomhet påvirke behandlingstilbudet til store pasientgrupper.

\section{Kjetil Søreide}

ksoreide@mac.com

Kirurgisk avdeling

Stavanger universitetssjukehus

4068 Stavanger

Oppgitte interessekonflikter: Ingen

\section{Litteratur}

1. Donaldson S. Congratulations to the 2009 editorial fellows. Radiology 2009; 253: 4-5.

2. Hayden JD. Readability in the British Journal of Surgery. Br J Surg 2008; 95: 119-24.

3. Søreide K, Winter DC. Global survey of factors influencing choice of surgical journal for manuscript submission. Surgery 2009; doi: 10.1016/j.surg. 2009.10.042. E-publisert 11.12.2009.

4. Glomsaker TB, Søreide K. Surgical training and working time restriction. Br J Surg 2009; 96: 329-30.

5. Søreide K. Epidemiology of major trauma. Br J Surg 2009; 96: 697-8.

Murie JA, Farndon JR. BJS in the new millennium. Br J Surg 2000; 87: 1-2

7. Alderson D, Earnshaw J. Two decades of excellence. Br J Surg 2010; doi 10.1002/bjs.6952.

8. Bretthauer M. Ett år i New England Journal of Medicine. Tidsskr Nor Legeforen 2009; 129: 1971. 